\title{
Allelopathic Effect of Aqueous Extract of Argemone mexicana $L$ on Germination and Growth of Brachiaria dictyoneura $\mathrm{L}$ and Clitoria ternatea $\mathrm{L}$
}

\author{
Hassan S. Namkeleja, Mokiti T. Tarimo, Patrick A. Ndakidemi
}

School of Life Sciences and Bioengineering, The Nelson Mandela African Institution of Science and Technology, Arusha, Tanzania. Email: ndakidemipa@gmail.com

Received August 11 ${ }^{\text {th }}, 2013$; revised September 11 ${ }^{\text {th }}, 2013$; accepted October $11^{\text {th }}, 2013$

Copyright (C) 2013 Hassan S. Namkeleja et al. This is an open access article distributed under the Creative Commons Attribution License, which permits unrestricted use, distribution, and reproduction in any medium, provided the original work is properly cited.

\begin{abstract}
The present study was conducted in the laboratory to investigate the allelopathic effect of Mexican poppy (Argemone mexicana L.) to the germination and growth parameters of two native species Brachiaria dictyoneura L and Clitoria ternatea L. Different concentrations of leaf and seed aqueous extracts from Argemone mexicana $(0 \%, 25 \%, 50 \%, 75 \%$ and $100 \%$ ) were evaluated. Results showed that seed germination, root length, shoot length, seedling length, fresh weight and dry weight of $B$. dictyoneura and $C$. ternatea seedlings were significantly reduced by leaf and seed extracts compared with control treatments. Roots were more affected than shoots; and leaf extract was more suppressive than seed extracts. From the results, it is concluded that leaf and seed extracts have some allelochemicals with inhibitory effect on germination and growth of the tested plant species.
\end{abstract}

Keywords: Allelochemicals; Root Length; Shoot Length

\section{Introduction}

Invasive alien plants are among the important factors that influence plants growth parameters in and among farming systems and wildlife ecosystems. Integrity of farming system and natural ecosystems are threatened by alien invasive species which displace some of the native species and establishing mono-species in new habitat [1-3]. Production and release of allelopathic compounds (allelochemicals) by invasive species are factors that enhance its competitive ability over native species [4]. Plants can affect neighboring plants by releasing chemicals into the environment [5]. The Austrian plant physiologist Hans Molisch named this phenomenon "allelopathy" in 1937 [6]. Allelopathy refers to the effects of one plant on another plant or organisms through the release of chemicals into the environment [2,7]. Allelochemicals released from plants, imposing allelopathic influences are classified as secondary metabolites and are produced as offshoots of the primary metabolic pathways in plants [8]. Allelopathic effect of some invasive species over other species is stronger in introduced habitats than in native lands because in new habitat native species may not be as adapted to specific allelochemicals of invaders as species do in the native range [4]. Mechanistically, allelochemicals have a role in the determination of nutrient dynamics, mycorrhizae, soil chemical characteristics and microbial ecology $[9,10]$. Allelochemicals released by invasive species also affect native species through different pathways that includes interruption of plants nutrients uptake, change in membrane permeability [11], interference in cell division and elongation process in roots and shoots [12-14], interference in chlorophyll formation [15] protein synthesis inhibition [11,16] and change or inactivate the activity and functions of certain hormones and enzymes [17]. Hence, allelopathy has been considered as among of key factor to the success of invasive plant species over native species [2-4,18]. Argemone mexicana (Mexican poppy) is amongst the ecologically and economically destructive exotic invasive plant species in Tanzania affecting both natural and agricultural ecosystems [19]. A. mexicana is a herb plant with branches, which has naturalized widely in many tropical and subtropical regions although it is a native of tropical American [20]. It is a widespread annual weed primarily associated with agricultural crops and wastelands. It is a major weed of a number of crops in the tropics and warm 
temperate regions and is persistent as it produces a seed bank. A. mexicana is amongst invasive weeds reported to release allelochemicals which affect some other species within its vicinity especially crops in agricultural fields. Burhan and Shaukat [21] reported the inhibition effect of A. Mexicana extracts in seed germination, root and shoot growth of pearl-millet, mustard, wheat, carrot, corn and turnip caused by allelopathic compounds dissolved in extracts. Another study by Paul and Begum [22] indicated that seed germination percentage, root length, shoot length and seedling dry weight of blackgram (Vigna mungo) and rapeseed (Brassica napus) were significantly decreased with the increase of both root and leaf extracts of A. mexicana. Alagesaboopathi [23] also reported that there was decrease in seed germination and inhibition of plumule and radicle length of Sorghum bicolor seedlings with increase in A. mexicana leaf extracts concentration due to allelopathic potentialities. Paul and Begum [24] reported allelopathic effect of $A$. mexicana on germination and seedling growth of Lentil (Lens culinaris). Allelopathic effect of $A$. mexicana retarded the growth of tomato plants at higher concentration [25].

All these researches have reported inhibitory effect in seed germination, root length and shoot length and other primary growth parameters caused by allelochemicals present in aqueous extracts. Although allelopathic effect of A. mexicana on crops (such as beans and maize) has been reported, little information is available on their influence on wild plant species. Therefore this study was conducted to investigate the allelopathic effect of leaf and seed aqueous extracts of $A$. mexicana on germination and seedling growth of $B$. dictyoneura and $C$. ternatea which are important pasture for wildlife and livestock. The data from this study will help in current efforts to eradicate alien invasive species (A. mexicana) in wildlife protected areas in Tanzania.

\section{Material and Methods}

\subsection{Preparation of the Aqueous Extract Solution}

Seeds and leaves of A. mexicana plants were collected at Ngorongoro Conservation Area (NCA). NCA is one of wildlife protected areas in Serengeti Ecosystem which has been invaded by A. mexicana. The Seeds and leaves were separately washed thoroughly with distilled water and air dried at room temperature for eight days. Seeds and leaves were separately crushed in a blander into powdery form and $100 \mathrm{~g}$ of these crushed materials were soaked separately in a corked, conical flask containing $1000 \mathrm{~mL}(1$ Liter $)$ of distilled water for 72 hours and filtered through Whatman filter paper No. 1. The extract was diluted to obtain the concentrations of 25 $\mathrm{g} \cdot \mathrm{L}^{-1}(25 \%), 50 \mathrm{~g} \cdot \mathrm{L}^{-1}(50 \%), 75 \mathrm{~g} \cdot \mathrm{L}^{-1}(75 \%)$, and 100 $\mathrm{g} \cdot \mathrm{L}^{-1}(100 \%)$ while the distilled water was used in the control treatment.

\subsection{Determination of Germination Percentage, Root Length, and Shoot Length}

The seeds of Brachiaria dictyoneura were collected from Ngorongoro Conservation Area and that of Clitoria ternatea were obtained from the National Plant Genetic Resources Centre of Tanzania at Tropical Pesticides Research Institute (TPRI) - Arusha Tanzania. The seeds were washed three times in running tap water to remove any impurities and afterwards surface sterilized with $5 \%$ of sodium hypochlorite for two minutes then rinsed four times with distilled water. Toxicity of aqueous extract of A. mexicana was tested against Brachiaria dictyoneura and Clitoria ternatea whereby 10 seeds of each target species were placed in $9 \mathrm{~cm}$ autoclave petri dishes lined up with double layer of whatman No. 1 filter paper and $10 \mathrm{~mL}$ of test extract for each concentration $(25 \%, 50 \%$, $75 \%$, and $100 \%$ ) of leaves and seeds. The seeds treated with distilled water were taken as a control $\left(\mathrm{T}_{0}\right)$ while seeds in petri dishes with four different concentrations $\left(\mathrm{T}_{1}=25 \%, \mathrm{~T}_{2}=50 \%, \mathrm{~T}_{3}=75 \%, \mathrm{~T}_{4}=100 \%\right)$ of Argemone mexicana extract constituted a four sets of treated seeds for each species (Brachiaria dictyoneura and Clitoria ternate). The petri dishes were covered by caps and kept inside the cupboards at room temperature. The experimental design was a randomized entire block with four replications for each treatment. Extract/distilled water were added to moisten the seeds when required.

Seeds were observed every day and number of germinated seeds was recorded (germination count) whereas the emergence of the radicle from the seed was considered as criterion for germination to be recorded. Germination was recorded every day (at 24 hours intervals) over a 10-day period. On 15th day after germination the root length, shoot length and seedling length were measured by using digital caliper while fresh weight and dry weights of each seedling were measured by digital weighing balance. The dry weight of each seedling was measured after placing them in an oven maintained at $55^{\circ} \mathrm{C}$ for 5 days.

\subsection{Statistical Analysis}

Percentage of inhibition/stimulation effect on germination and root and shoot elongation over control $\left(\mathrm{T}_{0}\right)$ was calculated using the equation used by Signh and Chaudhary [26]:

Inhibition $(-)$ or stimulation $(+)=[($ Germinated seeds in extracts - Germinated seed in control)/Geminate seeds in control] $\times 100$.

The data from the experiment was analyzed using the 
software of STATISTICA program 2013. When significant differences were detected by the analysis of variance (ANOVA), mean values of root length, shoot length, fresh weight and dry weight of seedlings were used to compare treatment means at $\mathrm{p}=0.05$ according to Fisher's Least Significant Difference (LSD).

\section{Results}

\subsection{Effects of Aqueous Extracts of A. mexicana on Seed Germination}

Table 1 presents mean seed germination percentages of $B$. dictyoneura and $C$. ternatea treated with different concentrations of seed and leaf aqueous extracts of $A$. mexicana. Seed and leaf aqueous extracts of A. mexicana significantly $(\mathrm{p} \leq 0.01)$ affected the germination of $B$. dictyoneura and $C$. ternatea seeds. Mean seed germination percentage of control treatments was high compared with seeds treated with aqueous extracts. The mean seed germination percentage was decreasing with increase in aqueous extracts concentration (Table 1). The mean germination percentage of $B$. dictyoneura seeds was $65 \%$, $50 \%, 12.5 \%$ and $7.5 \%$ when treated with concentrations of $25 \%, 50 \%, 75 \%$ and $100 \%$ leaf extracts respectively. Therefore when compared with control, the leaf extracts at the concentrations of $25 \%, 50 \%, 75 \%$ and $100 \%$ significantly inhibited $(\mathrm{p} \leq 0.001)$ germination of $B$. dictyoneura by $-31.6 \%,-47.4 \%,-86.8 \%$ and $-92.1 \%$ respectively. In seed extract, the percentage germination of $B$. dictyoneura were also significantly reduced $(\mathrm{p} \leq$ 0.001 ) with increase in concentration whereby at the concentration of $25 \%, 50 \%, 75 \%$ and $100 \%$ aqueous seed extracts, the germination was $70 \%, 50 \%, 32.5 \%$ and
$17.5 \%$ respectively. Relative to control treatment, the germination percentages were significantly reduced with increase in seed extracts concentration from $25 \%, 50 \%$, $75 \%$ and $100 \%$ and this inhibited germination of B. dictyoneura by $-24 \%,-45.9 \%,-64.8 \%$ and $-81.1 \%$ respectively. The similar trend was observed in seed germination of C. ternatea whereby at concentration of $25 \%$, $50 \%, 75 \%$ and $100 \%$ of leaf extract, the percentage germination were $77.5 \%, 77.5 \%, 37 \%$ and $25 \%$ respectively.

At concentrations of $25,50,75$ and $100 \%$, the germination of $C$. ternatea was significantly $(\mathrm{p} \leq 0.001)$ reduced by $-20.5 \%,-20.5 \%,-62.1 \%$ and $-74.4 \%$ respectively. Variation in mean germination percentage of $C$. ternatea was caused by inhibition effect that was increasing with increase in concentrations of leaf extracts when compared with the control treatment.

Mean germination percentages of $C$. ternate were also significantly reduced $(\mathrm{p} \leq 0.01)$ by $-24.2 \%,-26.3 \%$, $-36.8 \%$ and $-44.7 \%$ when treated with concentrations of $25 \%, 50 \%, 75 \%$ and $100 \%$ seed extracts respectively. Generally, germination inhibition was greater with $100 \%$ extract than with the other concentrations.

\subsection{Effects of Aqueous Extracts of Argemone mexicana on Roots and Shoots Elongation (mm)}

Root and shoot lengths of 15 days old seedlings of $C$. ternatea and $B$. dictyoneura treated with leaf and seed aqueous extracts of Argemone mexicana were much shorter in comparison with those of the control. The length of roots and shoots of $C$. ternatea and $B$. dictyo neura was decreasing with increase in concentrations of seed and leaf extracts.

Table 1. Effect of seed and leaf extracts of $A$. mexicana on germination percentage of $B$. dictyoneura and $C$. ternatea.

\begin{tabular}{|c|c|c|c|c|}
\hline \multirow[b]{2}{*}{ Extract Concentrations } & \multicolumn{2}{|c|}{ B. dictyoneura } & \multicolumn{2}{|c|}{ C. ternatea } \\
\hline & Seed Extracts & Leaf Extracts & Seed Extracts & Leaf Extracts \\
\hline $\mathrm{T}_{0}$ (Control) & $92.5 \pm 4.78 \mathrm{~d}$ & $95 \pm 5 \mathrm{c}$ & $95 \pm 2.88 \mathrm{c}$ & $97.5 \pm 2.5 \mathrm{c}$ \\
\hline \multirow{2}{*}{$\mathrm{T}_{1}(25 \%)$} & $70 \pm 4.08 \mathrm{c}$ & $65 \pm 5 b$ & $72.5 \pm 4.78 b$ & $77.5 \pm 8.54 b$ \\
\hline & $(-24)$ & $(-31.6)$ & $(-24.2)$ & $(-20.5)$ \\
\hline \multirow{2}{*}{$\mathrm{T}_{2}(50 \%)$} & $50 \pm 5.77 b$ & $50 \pm 5.77 \mathrm{~b}$ & $70 \pm 7.07 \mathrm{ab}$ & $77.5 \pm 4.79 b$ \\
\hline & $(-45.9)$ & $(-47.4)$ & $(-26.3)$ & $(-20.5)$ \\
\hline \multirow[t]{2}{*}{$\mathrm{T}_{3}(75 \%)$} & $32.5 \pm 4.78 \mathrm{ab}$ & $12.5 \pm 6.29 \mathrm{a}$ & $60 \pm 9.12 \mathrm{ab}$ & $37 \pm 2.5 \mathrm{a}$ \\
\hline & $(-64.8)$ & $(-86.8)$ & $(-36.8)$ & $(-62.1)$ \\
\hline \multirow[t]{2}{*}{$\mathrm{T}_{4}(100 \%)$} & $17.5 \pm 8.54 \mathrm{a}$ & $7.5 \pm 4.79 \mathrm{a}$ & $52.5 \pm 6.29 \mathrm{a}$ & $25 \pm 9.57 \mathrm{a}$ \\
\hline & $(-81.1)$ & $(-92.1)$ & $(-44.7)$ & $(-74.4)$ \\
\hline One way ANOVA (F Statistics) & $26.2037^{* * *}$ & $46.1357^{* * *}$ & $6.35^{* *}$ & $23.156^{* * *}$ \\
\hline
\end{tabular}

Values presented are means $\pm \mathrm{SE} .{ }^{*},{ }^{* *},{ }^{* * *}=$ significance at $\mathrm{p} \leq 0.05, \mathrm{p} \leq 0.01, \mathrm{p} \leq 0.001$ respectively. NS $=$ not significant, SE $=$ Standard error of mean. Means followed by similar letter in a column are not significantly different from each other at $\mathrm{p}=0.05$ according to LSD. Values in the parenthesis indicates percentage of the inhibitory $(-)$ effects in comparison with control $\left(\mathrm{T}_{0}\right)$. 
Roots length of $B$. dictyoneura treated with concentration of $25 \%, 50 \%, 75 \%$ and $100 \%$ seed extract were 20.4 , 16.4, 10.7 and $8.3 \mathrm{~mm}$ long respectively (Table 2 ). Root elongation inhibition percentages of seedlings treated with $25 \%, 50 \%, 75 \%$ and $100 \%$ of seed extracts was $-29.4 \%,-43.3 \%,-63 \%$ and $-71.3 \%$ respectively. Leaf extracts also significantly $(\mathrm{p} \leq 0.001)$ reduced roots elongation in comparison with control by $-36.1 \%$, $-50.3 \%,-66 \%$, and $-64.6 \%$ when treated at concentrations of $25 \%, 50 \%, 75 \%$ and $100 \%$ respectively.

In leaf extracts, the shortest roots were recorded at higher concentrations whereas longest was recorded in the control treatment. The shoot lengths of B. dictyoneura were significantly $(\mathrm{p} \leq 0.001)$ reduced by $-20.5 \%$, $-54.2 \%,-67.3 \%$ and $-68.6 \%$ at concentrations (seed extracts) of $25 \%, 50 \%, 75 \%$ and $100 \%$ respectively. The tallest shoot of $60.5 \mathrm{~mm}$ long was observed in control treatment while at concentrations of $25 \%, 50 \%, 75 \%$ and $100 \%$; shoot length was $48.1,27.7,19.8$ and $19 \mathrm{~mm}$ respectively. In leaf extracts, the tallest shoot of $60.1 \mathrm{~mm}$ was measured in control treatment compared with 46.8 , $25.5,19.9$ and $18.3 \mathrm{~mm}$ long, which was recorded in concentrations of $25 \%, 50 \%, 75 \%$ and $100 \%$ respectively. In comparison with control, shoot lengths were significantly $(\mathrm{p} \leq 0.001)$ reduced by $-22.1 \%,-57.6 \%,-66.9 \%$ and $-69.6 \%$ in leaf extracts with concentration of $25 \%$, $50 \%, 75 \%$ and $100 \%$ respectively.

The allelopathic effect of seed and leaf extract of $A$. mexicana on root and shoot lengths of C. ternatea is shown in Table 3. Root lengths of $C$. ternatea were reduced with increase in concentration of seed extracts. The mean root length of $C$. ternatea treated with distilled water (control) was $35 \mathrm{~mm}$ long while, the root length of seedlings treated with $25 \%, 50 \%, 75 \%$ and $100 \%$ extract concentrations was $31.3,24.5,24.3$ and $16.9 \mathrm{~mm}$ long respectively. Root length inhibition caused by seed extract at concentrations of $25 \%, 50 \%, 75 \%$ and $100 \%$ was $-10.6 \%,-30 \%,-30.6 \%$ and $-51.7 \%$ respectively. Root elongation of $C$. ternatea was also significantly ( $p \leq$ 0.001 ) hindered by different concentration of leaf extract whereby elongation inhibition was $-26.5 \%,-49.9 \%$, $-63.6 \%$ and $-83.5 \%$ at the concentrations of $25 \%, 50 \%$, $75 \%$ and $100 \%$ respectively. Mean root length in control treatment was $39.3 \mathrm{~mm}$ while in concentrations of $25 \%$, $50 \%, 75 \%$ and $100 \%$, the mean root length was 28.9 , $19.7,14.3$ and $6.5 \mathrm{~mm}$ respectively.

In comparison with control treatment, the allelopathic effect of leaf extract of $A$. mexicana reduced significantly ( $p \leq 0.01$ ) the shoot length of $C$. ternatea. At concentrations of $25 \%, 50 \%, 75 \%$ and $100 \%$, the shoot length was $81.4,74.8,94.5$ and $13.6 \mathrm{~mm}$ respectively. Shoot length inhibition caused by leaf extracts was $-22.5 \%,-28.8 \%$, $-10 \%$ and $-87 \%$ in response to extract concentrations of $25 \%, 50 \%, 75 \%$ and $100 \%$ respectively. Seed extracts of A. mexicana also reduced shoot length of $C$. ternatea but it was not significant.

\subsection{Effects of Aqueous Extracts of A. mexicana on Seedling Length $(\mathrm{mm})$}

Mean seedlings length of C. ternatea and B. dictyoneura treated with different concentrations of leaf and seed extracts of A. mexicana were much shorter in comparison with those of the control treatment (Table 4). Different concentrations of seed extracts significantly $(p \leq 0.05)$ reduced seedling length of $C$. ternatea by $-8.5,-10.5$, -23.6 and $-31.8 \%$ in response to seed extract concentrations of $25 \%, 50 \%, 75 \%$ and $100 \%$ respectively. Mean

Table 2. Effect of seed and leaf extracts of $A$. mexicana on root and shoot elongation and seedling growth of $B$. dictyoneura.

\begin{tabular}{|c|c|c|c|c|}
\hline \multirow[b]{2}{*}{ Extract Concentrations } & \multicolumn{2}{|c|}{ Seed Extracts } & \multicolumn{2}{|c|}{ Leaf Extracts } \\
\hline & Root Length (mm) & Shoot Length (mm) & Root Length (mm) & Shoot Length $(\mathrm{mm})$ \\
\hline $\mathrm{T}_{0}($ Control $)$ & $28.9 \pm 1.31 \mathrm{~d}$ & $60.5 \pm 0.43 d$ & $28.8 \pm 0.75 \mathrm{~d}$ & $60.1 \pm 1.15 \mathrm{~d}$ \\
\hline \multirow[t]{2}{*}{$\mathrm{T}_{1}(25 \%)$} & $20.4 \pm 0.01 \mathrm{c}$ & $48.1 \pm 1.68 \mathrm{c}$ & $18.4 \pm 0.085 \mathrm{c}$ & $46.8 \pm 1.14 \mathrm{c}$ \\
\hline & $(-29.4)$ & $(-20.5)$ & $(-36.1)$ & $(-22.1)$ \\
\hline \multirow[t]{2}{*}{$\mathrm{T}_{2}(50 \%)$} & $16.4 \pm 0.9 \mathrm{~b}$ & $27.7 \pm 1.41 b$ & $14.3 \pm 0.59 b$ & $25.5 \pm 1.13 b$ \\
\hline & $(-43.3)$ & $(-54.2)$ & $(-50.3)$ & $(-57.6)$ \\
\hline \multirow[t]{2}{*}{$\mathrm{T}_{3}(75 \%)$} & $10.7 \pm 0.23 \mathrm{a}$ & $19.8 \pm 0.96 \mathrm{a}$ & $9.80 \pm 1.33 \mathrm{a}$ & $19.9 \pm 0.41 \mathrm{a}$ \\
\hline & $(-63)$ & $(-67.3)$ & $(-66)$ & $(-66.9)$ \\
\hline \multirow[t]{2}{*}{$\mathrm{T}_{4}(100 \%)$} & $8.3 \pm 0.31 \mathrm{a}$ & $19.0 \pm 0.25 \mathrm{a}$ & $10.2 \pm 0.51 \mathrm{a}$ & $18.3 \pm 1.29 \mathrm{a}$ \\
\hline & $(-71.3)$ & $(-68.6)$ & $(-64.6)$ & $(-69.6)$ \\
\hline
\end{tabular}

Values presented are means $\pm \mathrm{SE} .{ }^{*},{ }^{* *},{ }^{* * *}=$ significance at $\mathrm{p} \leq 0.05, \mathrm{p} \leq 0.01, \mathrm{p} \leq 0.001$ respectively. NS $=$ not significant, $\mathrm{SE}=\mathrm{Standard}$ error of mean. Means followed by similar letter in a column are not significantly different from each other at $\mathrm{P}=0.05$ according to LSD. Values in the parenthesis indicates percentage of the inhibitory $(-)$ effects in comparison with control $\left(\mathrm{T}_{0}\right)$. 
Table 3. Effect of seed and leaf extracts of $A$. mexicana on root and shoot elongation $(\mathrm{mm})$ of $C$. ternatea.

\begin{tabular}{ccccc}
\hline & \multicolumn{2}{c}{ Seed Extracts } & \multicolumn{2}{c}{ Leaf Extracts } \\
\hline Extract Concentrations & Root Length $(\mathrm{mm})$ & Shoot Length $(\mathrm{mm})$ & Root Length $(\mathrm{mm})$ & Shoot Length $(\mathrm{mm})$ \\
\hline $\mathrm{T}_{0}(\mathrm{Control})$ & $35.0 \pm 1.75 \mathrm{~d}$ & $106.7 \pm 1.78 \mathrm{a}$ & $39.3 \pm 2.18 \mathrm{~d}$ & $105.0 \pm 1.88 \mathrm{~b}$ \\
$\mathrm{~T}_{1}(25 \%)$ & $31.3 \pm 3.0 \mathrm{~cd}$ & $98.4 \pm 6.58 \mathrm{ab}$ & $28.9 \pm 1.51 \mathrm{c}$ & $81.4 \pm 8.44 \mathrm{a}$ \\
& $(-10.6)$ & $(-7.8)$ & $(-26.50)$ & $(-22.50)$ \\
$\mathrm{T}_{2}(50 \%)$ & $24.5 \pm 1.51 \mathrm{~b}$ & $102.3 \pm 5.86 \mathrm{~b}$ & $19.7 \pm 3.11 \mathrm{~b}$ & $74.8 \pm 10.12 \mathrm{a}$ \\
& $(-30)$ & $(-4.1)$ & $(-49.9)$ & $(-28.8)$ \\
$\mathrm{T}_{3}(75 \%)$ & $24.3 \pm 4.24 \mathrm{abc}$ & $83.9 \pm 6.99 \mathrm{ab}$ & $14.3 \pm 0.88 \mathrm{ab}$ & $94.5 \pm 2.47 \mathrm{ab}$ \\
& $(-30.6)$ & $(-21.4)$ & $(-63.6)$ & $(-10)$ \\
$\mathrm{T}_{4}(100 \%)$ & $16.9 \pm 2.03 \mathrm{a}$ & $79.7 \pm 12.02 \mathrm{~b}$ & $6.5 \pm 0.0 \mathrm{a}$ & $13.6 \pm 0.0 \mathrm{c}$ \\
& $(-51.70)$ & $(-25.30)$ & $(-83.5)$ & $(-87)$ \\
One way ANOVA (F Statistics) & $9.8^{* * *}$ & $2.3 \mathrm{NS}$ & $23.688^{* * *}$ & $10.6397^{* *}$ \\
\hline
\end{tabular}

Values presented are means $\pm \mathrm{SE} .{ }^{*},{ }^{* *},{ }^{* * *}=$ significance at $\mathrm{p} \leq 0.05, \mathrm{p} \leq 0.01, \mathrm{p} \leq 0.001$ respectively. NS $=$ not significant, SE $=$ Standard error of mean. Means followed by similar letter in a column are not significantly different from each other at $\mathrm{p}=0.05$ according to LSD. Values in the parenthesis indicates percentage of the inhibitory $(-)$ effects in comparison with control $\left(\mathrm{T}_{0}\right)$.

Table 4. Effect of seed and leaf extracts of A. mexicana on seedling length (mm) of B. dictyoneura and C. ternatea.

\begin{tabular}{|c|c|c|c|c|}
\hline \multirow[b]{2}{*}{ Extract Concentrations } & \multicolumn{2}{|c|}{ C. ternatea } & \multicolumn{2}{|c|}{ B. dictyoneura } \\
\hline & Seed Extracts & Leaf Extracts & Seed Extracts & Leaf Extracts \\
\hline $\mathrm{T}_{0}($ Control $)$ & $141.7 \pm 3.31 b$ & $144.2 \pm 2.83 \mathrm{c}$ & $89.4 \pm 1.5 \mathrm{~d}$ & $88.8 \pm 1.89 \mathrm{~d}$ \\
\hline \multirow[t]{2}{*}{$\mathrm{T}_{1}(25 \%)$} & $129.6 \pm 6.56 \mathrm{ab}$ & $110.4 \pm 8.33 a$ & $68.5 \pm 1.67 \mathrm{c}$ & $65.2 \pm 1.54 \mathrm{c}$ \\
\hline & $(-8.5)$ & $(-23.4)$ & $(-23.4)$ & $(-26.6)$ \\
\hline \multirow[t]{2}{*}{$\mathrm{T}_{2}(50 \%)$} & $126.8 \pm 7.12 \mathrm{ab}$ & $97.4 \pm 13.79 \mathrm{a}$ & $44.1 \pm 2.25 b$ & $39.7 \pm 1.65 b$ \\
\hline & $(-10.5)$ & $(-32.5)$ & $(-50.7)$ & $(-55.3)$ \\
\hline \multirow[t]{2}{*}{$\mathrm{T}_{3}(75 \%)$} & $108.2 \pm 11.23 \mathrm{ac}$ & $108.8 \pm 1.59 \mathrm{a}$ & $30.5 \pm 1.14 \mathrm{a}$ & $29.6 \pm 1.48 \mathrm{a}$ \\
\hline & $(-23.6)$ & $(-24.5)$ & $(-65.9)$ & $(-66.6)$ \\
\hline \multirow[t]{2}{*}{$\mathrm{T}_{4}(100 \%)$} & $96.6 \pm 14.01 \mathrm{c}$ & $20.2 \pm 0.0 \mathrm{~b}$ & $27.3 \pm 0.51 \mathrm{a}$ & $28.5 \pm 0.78 \mathrm{a}$ \\
\hline & $(-31.8)$ & $(-86)$ & $(-69.5)$ & $(-67.9)$ \\
\hline One way ANOVA (F Statistics) & $4.07^{*}$ & $14.362^{* * *}$ & $267.277^{* * *}$ & $233.903^{* * *}$ \\
\hline
\end{tabular}

Values presented are means $\pm \mathrm{SE}^{*},{ }^{* *},{ }^{* * *}=$ significance at $\mathrm{p} \leq 0.05, \mathrm{p} \leq 0.01, \mathrm{p} \leq 0.001$ respectively. NS $=$ not significant, $\mathrm{SE}=\mathrm{Standard}$ error of mean. Means followed by similar letter in a column are not significantly different from each other at $\mathrm{p}=0.05$ according to LSD. Values in the parenthesis indicates percentage of the inhibitory $(-)$ effects $(\%)$ in comparison with control $\left(\mathrm{T}_{0}\right)$.

seedling lengths of C. ternatea in control treatment was $141.7 \mathrm{~mm}$ long while at concentrations of $25 \%, 50 \%$, $75 \%$ and $100 \%$ of seed extracts were $129.6,126.8,108.2$ and $96.6 \mathrm{~mm}$ respectively. In leaf extracts, seedling length of $C$. ternatea was significantly $(\mathrm{p} \leq 0.001)$ reduced as extract concentrations was increasing. Inhibition percentages of seedling length caused by leaf extract concentrations of $25 \%, 50 \%, 75 \%$ and $100 \%$ were $-23.4 \%,-32.5 \%,-24.5 \%$ and $-86 \%$ respectively. Mean seedling length of $C$. ternatea at concentrations of $25 \%$, $50 \%, 75 \%$ and $100 \%$ leaf extract of $A$. mexicana was 110.4, 97.4, 108.8 and $20.2 \mathrm{~mm}$ respectively. Hence seedling length was decreasing with increase in extract concentration relative to the control treatment in which the seedling length was $144.2 \mathrm{~mm}$ long. Mean seedlings length of $B$. dictyoneura treated with seed extracts of $A$. Mexicana were significantly $(\mathrm{p} \leq 0.001)$ reduced compared with control treatment by $-23.4 \%,-50.7 \%$, $-65.9 \%$ and $-69.5 \%$ in response to the concentrations of $25 \%, 50 \%, 75 \%$ and $100 \%$ respectively (Table 4). Increase in inhibition percentages caused the decrease in seedling lengths whereby in control treatment the mean seedling length of $89.4 \mathrm{~mm}$ long was recorded while at concentrations of $25 \%, 50 \%, 75 \%$ and $100 \%$ seedling length was $68.5,44.1,30.5$ and $27.3 \mathrm{~mm}$ respectively. The similar trend was observed in seedlings treated with leaf extracts whereby significant $(\mathrm{p} \leq 0.001)$ reduction in seedling lengths was observed with increasing concentrations in the extracts. Mean seedling lengths of B. dictyoneura in the control treatment was $88.8 \mathrm{~mm}$ while those 
treated with concentrations of $25 \%, 50 \%, 75 \%$ and $100 \%$ leaf extracts had length of $65.2,39.7,29.6$ and $28.5 \mathrm{~mm}$ respectively. Hence length inhibition impact caused by $A$. Mexicana leaf extract at concentrations of $25 \%, 50 \%$, $75 \%$ and $100 \%$ was $-26.6 \%,-55.3 \%,-66.6 \%$ and $-67.7 \%$ respectively.

\subsection{Effects of Aqueous Extracts of A. mexicana on Fresh Weight and Dry Weight (mg)}

Mean seedling fresh weight and dry weights of B. dictyoneura are presented in Table 5. The fresh weight and dry weight of $B$. dictyoneura seedlings were significantly $(\mathrm{p} \leq 0.001)$ affected upon treatment with different concentrations of leaf and seed extracts of A. mexicana. In seed and leaf extract of A. mexicana the fresh weight and dry weight of $B$. dictyoneura decreased with increasing concentrations in the extracts.

The mean fresh weights of B. dictyoneura in the control treatment was $22.3 \mathrm{mg}$ while at concentration of $25 \%$, $50 \%, 75 \%$ and $100 \%$ seed extracts, fresh weight was $15.5,12.1,8.5$ and $5.9 \mathrm{mg}$ respectively. Hence, in comparison with mean fresh weight in the control treatment, the fresh weight of $B$. dictyoneura at $25 \%, 50 \%, 75 \%$ and $100 \%$ seed extracts concentrations were reduced by $-30 \%,-45.7 \%,-61.9 \%$ and $-73.5 \%$ respectively.

With leaf extracts of $A$. mexicana, the mean fresh weights of $B$. dictyoneura decreased with increase in extracts concentration. Mean fresh weight of seedling treated with leaf extract at concentrations of $25 \%, 50 \%$, $75 \%$ and $100 \%$ was $22.7,12.9,10.7,10.1$ and $7.5 \mathrm{mg}$ respectively. In comparison with mean fresh weight of control treatment, the mean fresh weights at concentra- tions of $25 \%, 50 \%, 75 \%$ and $100 \%$ leaf extracts was significantly inhibited by $-43 \%,-52.9 \%,-55.6 \%$ and $-67 \%$ respectively.

Phytotoxin of seed extract of A. mexicana also inhibited dry weight of $B$. dictyoneura at different concentra tion levels. The highest dry seedling weight of $1.97 \mathrm{mg}$ was acquired in control treatment while at concentrations of $25 \%, 50 \%, 75 \%$ and $100 \%$ the mean dry weights were $1.4,0.63,0.29$, and $0.17 \mathrm{mg}$ respectively. The reduction percentage of seedling dry weight in the seed extract at concentrations of $25 \%, 50 \%, 75 \%$ and $100 \%$ were $-28.9 \%,-68 \%,-85 \%$ and $-91 \%$ respectively.

Results in Table 5 illustrate that the leaf extracts also significantly $(p \leq 0.001)$ decreased the seedling dry weight as compared with control treatment. The seedling dry weight of $1.8 \mathrm{mg}$ was obtained in control treatment, while dry weights of $0.5,0.33,0.27$ and $0.25 \mathrm{mg}$ were recorded at concentrations of $25 \%, 50 \%, 75 \%$ and $100 \%$ respectively. The inhibition effect in dry weights of seedlings treated with leaf extracts at concentration of $25 \%$, $50 \%, 75 \%$ and $100 \%$ were $-72.2 \%,-81.7 \%,-85 \%$, $-86.1 \%$ respectively.

Mean fresh weight and dry weights in Table 6, demonstrated that seed and leaf extracts of A. mexicana sig nificantly decreased the seedling fresh and dry weight of C. ternatea as compared with control treatment.

Mean fresh weight of $C$. ternatea treated with seed extracts significantly decreased by $-5 \%,-17 \%,-22 \%$ and $-28 \%$ when treated with seed extract at concentrations of $25 \%, 50 \%, 75 \%$ and $100 \%$ respectively. Thereafter, the mean fresh weight of $C$. ternatea in the control treatment was $340 \mathrm{mg}$, while at concentrations of $25 \%, 50 \%, 75 \%$

Table 5. Effect of seed and leaf extracts of $A$. mexicana on fresh and dry weight of Brachiaria dictyoneura.

\begin{tabular}{|c|c|c|c|c|}
\hline \multirow[b]{2}{*}{ Extract Concentrations } & \multicolumn{2}{|c|}{ Seed Extracts } & \multicolumn{2}{|c|}{ Leaf Extracts } \\
\hline & Fresh Weight (mg) & Dry Weight (mg) & Fresh Weight (mg) & Dry Weight (mg) \\
\hline $\mathrm{T}_{0}($ Control $)$ & $22.3 \pm .29 \mathrm{~d}$ & $1.97 \pm 0.25 b$ & $22.75 \pm 1.89 \mathrm{c}$ & $1.8 \pm 0.11 \mathrm{~b}$ \\
\hline \multirow[t]{2}{*}{$\mathrm{T}_{1}(25 \%)$} & $15.6 \pm 0.71 \mathrm{c}$ & $1.4 \pm 0.37 b$ & $12.97 \pm 0.58 \mathrm{~b}$ & $0.5 \pm 0.18 \mathrm{a}$ \\
\hline & $(-30)$ & $(-28.9)$ & $(-43)$ & $(-72.2)$ \\
\hline \multirow[t]{2}{*}{$\mathrm{T}_{2}(50 \%)$} & $12.1 \pm 0.74 \mathrm{~b}$ & $0.63 \pm 0.11 \mathrm{a}$ & $10.71 \pm 0.59 \mathrm{ab}$ & $0.33 \pm 0.19 \mathrm{a}$ \\
\hline & $(-45.7)$ & $(-68)$ & $(-52.9)$ & $(-81.7)$ \\
\hline \multirow[t]{2}{*}{$\mathrm{T}_{3}(75 \%)$} & $8.5 \pm 1.28 \mathrm{a}$ & $0.29 \pm 0.01 \mathrm{a}$ & $10.1 \pm 0.59 \mathrm{ab}$ & $0.27 \pm 0.17 \mathrm{a}$ \\
\hline & $(-61.9)$ & $(-85.3)$ & $(-55.6)$ & $(-85)$ \\
\hline \multirow[t]{2}{*}{$\mathrm{T}_{4}(100 \%)$} & $5.9 \pm 0.81 \mathrm{a}$ & $0.17 \pm 0.04 \mathrm{a}$ & $7.5 \pm 0.7 \mathrm{a}$ & $0.25 \pm 0.15 \mathrm{a}$ \\
\hline & $(-73.5)$ & $(-91.4)$ & $(-67)$ & $(-86.1)$ \\
\hline One way ANOVA (F Statistics) & $37.8702^{* * *}$ & $12.226^{* * *}$ & $27.051^{* * *}$ & $16.614^{* * *}$ \\
\hline
\end{tabular}

Values presented are means $\pm \mathrm{SE} .{ }^{*},{ }^{* *},{ }^{* * *}=$ significance at $\mathrm{p} \leq 0.05, \mathrm{p} \leq 0.01, \mathrm{p} \leq 0.001$ respectively. NS $=$ not significant, $\mathrm{SE}=\mathrm{Standard}$ error of mean. Means followed by similar letter in a column are not significantly different from each other at $\mathrm{p}=0.05$ according to LSD. Values in the parenthesis indicates percentage of the inhibitory $(-)$ effects in comparison with control $\left(\mathrm{T}_{0}\right)$. 
Table 6. Effect of seed and leaf extracts of $A$. mexicana on fresh and dry weight of Clitoria ternatea.

\begin{tabular}{ccccc}
\hline & \multicolumn{2}{c}{ Seed Extracts } & \multicolumn{2}{c}{ Leaf Extracts } \\
\hline Extract Concentrations & Fresh Weight $(\mathrm{mg})$ & Dry Weight $(\mathrm{mg})$ & Fresh Weight (mg) & Dry Weight (mg) \\
\hline $\mathrm{T}_{0}($ Control) & $340 \pm 15.31 \mathrm{c}$ & $33.5 \pm 2.08 \mathrm{c}$ & $343 \pm 7.9 \mathrm{~b}$ & $35.1 \pm 1.64 \mathrm{c}$ \\
$\mathrm{T}_{1}(25 \%)$ & $321.7 \pm 17.77 \mathrm{bc}$ & $25.4 \pm 3.07 \mathrm{~b}$ & $240.9 \pm 30.9 \mathrm{a}$ & $18.2 \pm 1.83 \mathrm{ab}$ \\
& $(-5)$ & $(-24)$ & $(-30)$ & $(-48)$ \\
$\mathrm{T}_{2}(50 \%)$ & $282.5 \pm 15.94 \mathrm{ab}$ & $15.4 .0 \pm 2.26 \mathrm{a}$ & $168.0 \pm 29.9 \mathrm{a}$ & $13.7 \pm 1.71 \mathrm{a}$ \\
& $(-17)$ & $(-54)$ & $(-51)$ & $(-61)$ \\
$\mathrm{T}_{3}(75 \%)$ & $263.9 \pm 47.52 \mathrm{ab}$ & $13.9 \pm 1.25 \mathrm{a}$ & $144.8 \pm 45.46 \mathrm{a}$ & $13.7 \pm 4.13 \mathrm{a}$ \\
& $(-22)$ & $(-59)$ & $(-58)$ & $(-61)$ \\
$\mathrm{T}_{4}(100 \%)$ & $243.4 \pm 18.74 \mathrm{a}$ & $11.9 \pm 1.37 \mathrm{a}$ & $134.5 \pm 0.0 \mathrm{a}$ & $10.2 \pm 0.0 \mathrm{a}$ \\
& $(-28)$ & $(-64)$ & $(-61)$ & $(-71)$ \\
One way ANOVA (F Statistics) & $4.305^{*}$ & $16.25^{* * *}$ & $8.99^{* *}$ & $65.87^{* * *}$ \\
\hline
\end{tabular}

Values presented are means $\pm \mathrm{SE} .{ }^{*},{ }^{* *},{ }^{* * *}=$ significance at $\mathrm{p} \leq 0.05, \mathrm{p} \leq 0.01, \mathrm{p} \leq 0.001$ respectively. NS $=$ not significant, $\mathrm{SE}=\mathrm{Standard}$ error of mean. Means followed by similar letter in a column are not significantly different from each other at $\mathrm{p}=0.05$ according to LSD. Values in the parenthesis indicates the percentage of inhibitory (-)effects in comparison with control $\left(\mathrm{T}_{0}\right)$.

and $100 \%$ fresh weight was $321.7,282.5,263.9$ and $243.4 \mathrm{mg}$ respectively. Similar trend was evident with leaf extract whereby the mean fresh weight of $C$. ternatea decreased with increasing concentrations of $\mathrm{A}$. mexicana. Mean fresh weight at concentrations of $25 \%$, $50 \%, 75 \%$ and $100 \%$ leaf extract was $240.9,168,144.8$ and $134.5 \mathrm{mg}$ respectively. Relative to the control treatment, the mean fresh weight of $C$. ternatea treated with concentration of $25 \%, 50 \%, 75 \%$ and $100 \%$ leaf extract were significantly $(\mathrm{p} \leq 0.01)$ reduced by $-30 \%,-51 \%$, $-58 \%$ and $-61 \%$ respectively Dry weight of $C$. ternatea was significantly $(\mathrm{p} \leq 0.01)$ reduced by seed extracts compared with the control treatment (Table 6). The decrease in seedling dry weight with seed extracts was $-24 \%,-54 \%,-59 \%$ and $-64 \%$ in response to seed extracts concentrations of $25 \%, 50 \%, 75 \%$ and $100 \%$ respectively. Hence, the highest dry weight of $33.5 \mathrm{mg}$ was acquired in the control treatment while at concentrations of $25 \%, 50 \%, 75 \%$ and $100 \%$ seed extracts, the dry weight were $25.4,15.4,13.9$ and $11.9 \mathrm{mg}$ respectively. In leaf extracts of $A$. mexicana, the trend of dry weights was similar to that of seed extracts whereby dry weight of $C$. ternatea decreased with increasing concentration. Dry weight of seedlings in the control treatment was higher (35.1 mg) than seedlings that treated with leaf extracts of different concentrations. Dry weights of C. ternatea seedlings were $18.2,13.7,13.7$, and $10.2 \mathrm{mg}$ in response to leaf extract concentrations of $25 \%, 50 \%, 75 \%$ and $100 \%$ respectively. Therefore, mean dry weights of $C$. ternatea were inhibited by $-48 \%,-61 \%,-61 \%$ and $-71 \%$ when treated with leaf extract at concentrations of $25 \%, 50 \%, 75 \%$ and $100 \%$ respectively.

\section{Discussion}

This study clearly shows that there is phototoxic effect of aqueous extracts of leaves, and seeds of $A$. mexicana on the germination and growth of $C$. ternatea and B. dictyoneura. Higher concentrations of leaf and seed extracts had a higher degree of germination inhibition. This might have been caused by some of allelochemicals present in leaf and seed aqueous extracts of $A$. mexicana. These results correlates with studies conducted by Burhan and Shaukat, [21] Paul and Begum [22] and Alagesaboopathi [23] who reported seed germination inhibition of Sorghum bicolor, carrot, wheat, mustard, turnip, pearl-millet, blackgram, rapeseed wheat and corn with increase in $A$. mexicana leaf and shoot extracts concentration. The germination reductions in these studies were related to the allelopathic potential of $A$. Mexican. In detailed studies, Rice, [27] revealed that some of allelochemicals interrupted the mitotic activity of young cells, resulting in the inhibition of seed germination. Similar to our study, several researchers have reported germination inhibition in some cultivated crop species. For instance, Chandra et al. [28] and Esmaeili et al. [29] reported that salicylic and vanillic inhibited seed germination of cowpea (Vigna unguiculata) and Barnyard grass (Echinochloa crus-galli L) respectively.

In this study, shoot, root and seedling growth of $C$. ternatea and $B$. dictyoneura treated with different concentrations of seed and leaf extracts of $A$. mexicana were reduced with increasing concentrations. Reduction in seedling growth might have been caused by some of allelochemicals. According to studies by Cruz-Ortega et al. [12] Colpas et al. [13] and Cruz et al. [14] some al- 
lelochemicals from A. mexicana were reported to interrupt the process of cell division and elongation in roots and shoots which in turn reduced the seedling growth. Barkosky and Einhellig [30] also found that the growth of soybean seedlings was reduced with high concentrations of phydroxybenzoic acid. Chen et al. [31] postulated that exudates of vanillin and cinnamic acid posed allelopathic effect on egg plant seedling growth at high level concentration. Elsewhere, other researchers found that cinnamic acid was an allelochemical responsible for allelopathy for root growth in cucumber [32] and shoot and root length of cabbage seedlings [33]. Hence results on seedling growth found in this study conforms to findings reported by Alagesaboopathi [23]; Paul and Begum [24]; Jilani et al. [25]; Burhan and Shaukat [21] who reported allelopathic effect of $A$. mexicana on the growth of tomato, sorghum, lentil, carrot, wheat, mustard, turnip, pearlmillet, corn, blackgram and rapeseed.

In comparative analysis between control treatment and aqueous extract treatments, the root lengths were greatly inhibited than shoot lengths. The difference in the extents to which roots and shoots were affected by aqueous extracts in this study may be due to the contact of the roots with the filter paper, leading to constant absorption of the extract solution [34]. Also Nishida et al. [35] postulated that permeability of allelochemicals to root tissues is greater than in shoots. Chon et al. [36] reported that root length is good indicator of allelopathic effect of plant extracts because it is more sensitive to phytotoxic compounds than shoot growth. Keshavarzi et al. [37] also concluded that extracts has more impact on radicle length, because it has direct contact with radicle. Similar kind of observation was also reported by Sarkar et al. [34] who studied allelopathic effect of Cassia tora on seed germination and growth of mustard.

The present study also found that seed and leaf extract of A. mexicana significantly reduced fresh and dry weights of $B$. dictyoneura and $C$. ternatea with increasing extracts concentration. Decrease in fresh and dry weight might be attributed to allelochemicals inhibiting protein and carbohydrate synthesis and hence reducing seedling growth $[11,16,38]$. Similar to our study, Alagesaboopathi [23] also reported the decrease in fresh and dry weights of sorghum upon treatment with different concentrations of $A$. mexicana leaf aqueous extracts.

Overall, leaf extracts were found to have more allelopathic effect compared with seed extracts in most of parameters tested. Similar findings were also reported by Paul and Begum [22]; Cipollini and Flint [39] in blackgram, rapeseed, wheat and native woodland plants. Moreover, in this study the allelopathic effects of leaf and seed extracts of $A$. mexicana was stronger in grass species (B. dictyoneura) than in the leguminous species
(C. ternatea). This observation might be due to the fact that some leguminous species has allelopathic potentials. Study done by Piyatida and Kato-Nunguchi [40] concluded that $C$. ternatea has inhibitory effect on the growth of lettuce (Lactuca sativa L), alfalfa (Medicago sativa $\mathrm{L}$ ) and timothy (Phleum pretence $\mathrm{L}$ ).

\section{Conclusion}

From the present study, it is evident that, A. mexicana has allelopathic effect on the germination, growth and development of $C$. ternatea and B. dictyoneura. The allelochemicals compounds in A. mexicana might have inhibited the seed germination, seedling growth in the tested plant species. However, the inhibition was dose dependent as there was great inhibition at higher extract concentrations. A. mexicana being allelopathic and invasive alien species in Tanzania it should be controlled in natural ecosystems and agricultural fields otherwise may suppress crops and native plant species. However, further research is needed to isolate and identify specific allelochemicals presented in A. mexicana and mechanisms which caused inhibition in the tested species.

\section{Acknowledgements}

Many thanks are due to Dr Margaret J Mollel from National Plant Genetic Resources Centre of Tanzania at TPRI for providing seeds used in this study and Laboratory scientists at the Nelson Mandela African Institute of Science and Technology (NM-AIST Laboratory) for their valuable assistance during the course of the research. This study was funded by Tanzania Commission for Science and Technology (COSTECH) through the Nelson Mandela African Institution of Science and Technology.

\section{REFERENCES}

[1] R. M. Callaway and E. T. Aschehoug, "Invasive Plants versus Their New and Old Neighbors: A Mechanism for Exotic Invasion," Science, Vol. 290, No. 5491, 2000, pp. 521-523. http://dx.doi.org/10.1126/science.290.5491.521

[2] H. P. Bais, R. Vepachedu, S. Gilroy, R. M. Callaway and J. M. Vivanco, "Allelopathy and Exotic Plant Invasion: From Molecules and Genes to Species Interactions," Science, Vol. 301, No. 5638, 2003, pp. 1377-1380. http://dx.doi.org/10.1126/science.1083245

[3] T. R. Seastedt, R. M. Callaway, J. L. Pollock and J. Kaur, "Allelopathy and Plant Invasions: Traditional, Congeneric, and Bio-Geographical Approaches," Biological Invasions, Vol. 10, No. 6, 2008, pp. 875-890. http://dx.doi.org/10.1007/s10530-008-9239-9

[4] R. M. Callaway and W. M. Ridenour, "Novel Weapons: Invasive Success and the Evolution of Increased Competitive Ability," Frontiers in Ecology and the Environ- 
ment, Vol. 2, No. 8, 2004, pp. 436-443. http://dx.doi.org/10.1890/1540-9295(2004)002[0436:NW ISAT $72.0 . \mathrm{CO} ; 2$

[5] H. B. He, H. B. Wang, C. X. Fang, Z. H. Lin, Z. M. Yu and W. X. Lin, "Separation of Allelopathy from Resource Competition Using Rice/Barnyardgrass Mixed-Cultures," PloS One, Vol. 7, No. 5, 2012, Article ID: e37201. http://dx.doi.org/10.1371/journal.pone.0037201

[6] S. Narwal, R. Palaniraj and S. Sati, "Role of Allelopathy in Crop Production," Herbologia, Vol. 6, No. 20, 2005, pp. 327-332.

[7] R. M. Callaway, "The Detection of Neighbors by Plants," Trends in Ecology \& Evolution, Vol. 17, No. 3, 2002, pp. 104-105.

http://dx.doi.org/10.1016/S0169-5347(01)02438-7

[8] M. An, "Mathematical Modelling of Dose-response Relationship (Hormesis) in Allelopathy and Its Application," Nonlinearity in Biology, Toxicology, and Medicine, Vol. 3, No. 2, 2005, pp. 153-172. http://dx.doi.org/10.2201/nonlin.003.02.001

[9] S. Mangla and R. M. Callaway, "Exotic Invasive Plant Accumulates Native Soil Pathogens Which Inhibit Native Plants," Journal of Ecology, Vol. 96, No. 1, 2008, pp. 5867.

[10] K. O. Reinhart and R. M. Callaway, "Soil Biota and Invasive Plants," New Phytologist, Vol. 170, No. 3, 2006, pp. 445-457.

http://dx.doi.org/10.1111/j.1469-8137.2006.01715.x

[11] Z.-H. Li, Q. Wang, X. Ruan, C.-D. Pan and D.-A. Jiang, "Phenolics and Plant Allelopathy," Molecules, Vol. 15, No. 12, 2010, pp. 8933-8952.

http://dx.doi.org/10.3390/molecules 15128933

[12] R. Cruz-Ortega, A. Lara-Núñez and A. L. Anaya, "Allelochemical Stress Can Trigger Oxidative Damage in Receptor Plants: Mode of Action of Phytotoxicity," Plant Signaling \& Behavior, Vol. 2, No. 4, 2007, pp. 269-270. http://dx.doi.org/10.4161/psb.2.4.3895

[13] F. T. Colpas, E. O. Ono, J. D. Rodrigues, J. R. de S. Passos, "Effects of Some Phenolic Compounds on Soybean Seed Germination and on Seed-Borne Fungi," Brazilian Archives of Biology and Technology, Vol. 46, No. 2, 2003, pp. 155-161. http://dx.doi.org/10.1590/S1516-89132003000200003

[14] R. Cruz-Ortega, A. L. Anaya, B. E. Hernández-Bautista and G. Laguna-Hernández, "Effects of Allelochemical Stress Produced by Sicyos deppei on Seedling Root Ultrastructure of Phaseolus vulgaris and Cucurbita ficifolia," Journal of Chemical Ecology, Vol. 24, No. 12, 1998, pp. 2039-2057. http://dx.doi.org/10.1023/A:1020733625727

[15] L. Chen, L. Liao, S. Wang, Z. Huang and F. Xiao, "Effect of Vanillin and P-hydroxybenzoic acid on Physiological Characteristics of Chinese Fir Seedlings," The journal of Applied Ecology, Vol. 13, No. 10, 2002, pp. 1291-1294.

[16] T. L. Weir, S.-W. Park and J. M. Vivanco, "Biochemical and Physiological Mechanisms Mediated by Allelochemicals," Current Opinion in Plant Biology, Vol. 7, No. 4,
2004, pp. 472-479.

http://dx.doi.org/10.1016/j.pbi.2004.05.007

[17] S. Muzaffar, B. Ali and N. A. Wani, "Effect of Catechol, Gallic Acid and Pyrogallic Acid an the Germination, Seedling Growth and the Level of Endogenous Phenolics in Cucumber (Cucumis sativus L.)," International Journal of Life Science Biotechnology and Pharma Research, Vol. 1, No. 3, 2012, pp. 50-55.

[18] Y. Yuan, B. Wang, S. Zhang, J. Tang, C. Tu, S. Hu, J. W. Yong and X. Chen, "Enhanced Allelopathy and Competitive Ability of Invasive Plant Solidago canadensis in Its Introduced Range," Journal of Plant Ecology, Vol. 6, No. 3, 2013, pp. 253-263. http://dx.doi.org/10.1093/jpe/rts033

[19] A. Sanaa, "Perspectives on the Relationship Between Invisibility, Richness, Plant Size, Seed Production, Seed Bank and Community Productivity of Invasive Argemone ochroleuca Sweet in Taif, Saudi Arabia," Life Science Journal, Vol. 9, No. 2, 2012, p. 953.

[20] I. A. Siddiqui, S. S. Shaukat, G. H. Khan and M. Zaki, "Evaluation of Argemone mexicana for Control of RootInfecting Fungi in Tomato," Journal of Phytopathology, Vol. 150, No. 6, 2002, pp. 321-329. http://dx.doi.org/10.1046/j.1439-0434.2002.00762.x

[21] N. Burhan and S. S. Shaukat, "Allelopathic Potential of Argentone mexicana L. A Tropical Weed," Pakstan Journal of Biological Science, Vol. 2, No. 4, 1999, pp. 1268-1273. http://dx.doi.org/10.3923/pjbs.1999.1268.1273

[22] N. Paul and N. Begum, "Influence of Root and Leaf Extracts of Argemone mexicana on Germination and Seedling Growth of Blackgram, Rapeseed and Wheat," Bangladesh Journal of Scientific and Industrial Research, Vol. 42, No. 2, 2007, pp. 229-234. http://dx.doi.org/10.3329/bjsir.v42i2.477

[23] C. Alagesaboopathi, "Allelopathic Effect of Different Concentration of Water Extract of Argemone mexicana L. on Seed Germination and Seedling Growth of Sorghum bicolor (L.) Moench," Journal of Pharmacy and Biological Sciences, Vol. 5, No. 1, 2013, pp. 52-55. http://dx.doi.org/10.9790/3008-0515255

[24] N. Paul and N. Begum, "Allelopathic Effect of Argemone mexicana L. on Germination and Seedling Growth Characteristics of Lentil (Lens culinaris)," Journal of BioScience, Vol. 18, 2010, pp. 146-147.

[25] G. Jilani, S. Mahmood, A. N. Chaudhry, I. Hassan and M. Akram, "Allelochemicals: Sources, Toxicity and Microbial Transformation in Soil-A Review," Annals of Microbiology, Vol. 58, No. 3, 2008, pp. 351-357. http://dx.doi.org/10.1007/BF03175528

[26] A. P. Signh and B. R. Chaudhary, "Allelopathic Potential of Algal Weed Pithora oedogonia (Mont) Ittrock on the Germination and Seedling Growth of Oryza sativa," Botany Research International, Vol. 4, No. 2, 2011, pp. 3640.

[27] E. L. Rice, “Allelopathy,” Academic Press, London, 1984.

[28] A. Chandra, A. Anand and A. Dubey, "Effect of Salicylic Acid on Morphological and Biochemical Attributes in 
Cowpea," Journal of Environmental Biology, Vol. 28, No. 2, 2007, pp. 193-196.

[29] M. Esmaeili, A. Heidarzadel, H. Pirdashti and F. Exmaeili, "Inhibitory Activity of Pure Allelochemicals on Barnyard grass (Echinochloa crus-galli L) Seed and Seedling Parameters," International Journal of Agriculture and Crop Sciences, Vol. 4, No. 6, 2012, pp. 274-279.

[30] R. R. Barkosky and F. A. Einhellig, "Allelopathic Interference of Plant-Water Relationships by Para-Hydroxybenzoic Acid," Botanical Bulletin of Academia Sinica, Vol. 44, No. 1, 2003, pp. 53-58.

[31] S. Chen, B. Zhou, S. Lin, X. Li and X. Ye, "Accumulation of Cinnamic Acid and Vanillin in Eggplant Root Exudates and the Relationship with Continuous Cropping Obstacle," African Journal of Biotechnology, Vol. 10, No. 14, 2011, pp. 2659-2665.

[32] J. Ding, Y. Sun, C. L. Xiao, K. Shi, Y. H. Zhou and J. Q. Yu, "Physiological Basis of Different Allelopathic Reactions of Cucumber and Figleaf gourd Plants to Cinnamic acid," Journal of Experimental Botany, Vol. 58, No. 13, 2007, pp. 3765-3773. http://dx.doi.org/10.1093/jxb/erm227

[33] N. Singh, K. Yadav and N. Amist, "Phytotoxic Effects of Cinnamic Acid on Cabbage (Brassica oleracea var. Capitata)," Journal of Stress Physiology \& Biochemistry, Vol. 9, No. 2, 2013, pp. 307-317.

[34] E. Sarkar, S. N. Chatterjee and P. Chakraborty, "Allelopathic Effect of Cassia tora on Seed Germination and growth of Mustard," Turkish Journal of Botany, Vol. 36, No. 5, 2012, pp. 488-494.

[35] N. Nishida, S. Tamotsu, N. Nagata, C. Saito and A. Sakai, "Allelopathic Effects of Volatile Monoterpenoids Pro- duced by Salvia leucophylla: Inhibition of Cell Proliferation and DNA Synthesis in the Root Apical Meristem of Brassica campestris Seedlings," Journal of Chemical Ecology, Vol. 31, No. 5, 2005, pp. 1187-1203. http://dx.doi.org/10.1007/s10886-005-4256-y

[36] S. U. Chon, J. H. Coutts and C. J. Nelson, "Effects of Light, Growth Media, and Seedling Orientation on Bioassays of Alfalfa Autotoxicity," Agronomy Journal, Vol. 92, No. 4, 2000, pp. 715-720. http://dx.doi.org/10.2134/agronj2000.924715x

[37] M. H. B. Keshavarzi, M. J. Shakouri, P. G. Saman, M. H Porkareh, R Koorgol and E. Khosravi, "Effect of Allelopathic Activity of Annual Wormwood on Seed Germination and Seedling Growth of Brassica napus L.," Annals of Biological Research, Vol. 2, No. 3, 2011, pp. 529-532.

[38] D. R. Batish, K. Lavanya, H. P. Singh and R. K. Kohli, "Phenolic Allelochemicals Released by Chenopodium murale Affect the Growth, Nodulation and Macromolecule Content in Chickpea and Pea," Plant Growth Regulation, Vol. 51, No. 2, 2007, pp. 119-128. http://dx.doi.org/10.1007/s10725-006-9153-z

[39] K. A. Cipollini and W. N. Flint, "Comparing Allelopathic Effects of Root and Leaf Extracts of Invasive Alliaria petiolata, Lonicera maackii and Ranunculus ficaria on Germination of Three Native Woodland Plants," The Ohio Journal of Science, Vol. 112, No. 2, 2013, pp. 3743.

[40] P. Piyatida and H. Kato-Noguchi, "Screening of Allelopathic Activity of Eleven Thai Medicinal Plants on Seedling Growth of Five Test Plant Species," Asian Journal of Plant Sciences, Vol. 9, No. 8, 2010, pp. 491-486. http://dx.doi.org/10.3923/ajps.2010.486.491 